\title{
ACLS Report on Research Libraries
}

The American Council of Learned Societies Committee on Research Libraries has recently completed its report and forwarded it to the National Advisory Commission on Libraries. The following is from a preliminary statement on the study by its staff director Thomas P. Brockway, and is quoted here from the ACLS Newsletter with permission.

While it will be some weeks before the ACLS Committee report can be made available, the steps by which the report moves to the White House, and the several stages by which recommended action is taken by the Congress or other body or agency, suggest that much more time may elapse before library problems are directly dealt with.

In the meantime it may be possible for research libraries, the scholars who use them, and the universities to go farther than they have gone to date to analyze the problems that must be faced, examine alternative solutions, and enter upon a course of action. (While the remarks that follow refer to university libraries, the ACLS Committec of course considered the needs of all research libraries, and noted particularly the difficulties of unaffiliated research libraries with no contributory alumni and inadequate endowment.)

The library journals often describe measures of self-help by which individual libraries are attempting to overcome such lacks as the shortage of librarians. Doubtless considerable research must be done before any long-term programs can be designed. However, while the library schools and the Association of Research Libraries gather data and analyze needs, the individual library can act if it has the support and collaboration of the university administration. The library may be able to increase the adequacy of its staff by such measures as job analysis, in-service training programs, the automation of library operations, leaves for summer institutes and graduate studies, etc. On the one hand job analysis would show the extent to which trained librarians are doing clerical work that might be satisfactorily performed by anyone after a moderate term of instruction. On the other hand it may be possible to extend the range of competence in the existing professional staff by planned leaves for special training and study.

What can the scholar do for the library? Traditionally the librarian maintains a formal relationship with the faculty through a committee of departmental representatives. At a recent conference of research librarians such committees were described as weak-minded, listless, dormant, and virtually functionless. The right of equal time need not be claimed, for the judgment was institutional rather than personal; and everyone will agree that a committee must have a function and it must have responsibility if it is to serve any useful function.

Whether or not the librarian can bring his faculty committee to life, he needs allies on the faculty, whether he is defending his budget or struggling with bibliographical puzzles. Interdisciplinary studies confront the librarian with special problems, particularly when the research materials are not readily available, and, when acquired, cannot be read by anyone on the library staff. In such cases the scholar may have to help with bibliography and acquisition. A dramatic example of scholarly initiative backed enthusiastically by the librarian and the administration comes from Indiana University. The International Affairs Center there arranged an exchange with the Institute of History at the Czechoslovak Academy of Sciences by which Indiana is to receive 4,000 bound volumes of significant Czech books, journals, and newspapers, in return for 500 American books and two fellowships at Indiana. This brilliant barter of goods and services has a term of three years after which it can be renewed. The librarian's enthusiasm as he looks forward to the cataloging of $4,000 \mathrm{Czech}$ volumes suggests that there must be a secret codicil to the exchange agreement which guarantees the library the services of a few Czechreading graduate students when the books arrive. This is not assuming that they would do anything more than translate though linguistic skill is one of the approaches to a library career.

Without the wholehearted support of the administration, there is not a great deal the university librarian can do to extricate himself from the difficulties in which he is caught. In the rapid expansion of higher education mentioned above there is evidence that the needs of the library have been seriously under-rated. In many cases university administrators have failed to take into account the impact of greatly increased graduate study, the proliferation of new areas of research and instruction with their demand for instant collections, and sharply rising library costs.

A librarian in the Middle West has written of an illusion shared even by university presidents that the librarian has "large, uncommitted amounts of cash stashed away in his desk drawer under the three by five cards"; and on another occasion he said that if the university budget is tight the library is the 
first to be cut. The explanation is offered by the chancellor of a Middle Western university: "University administrators all too often consider library financing as postponable. When funds are tight, library requests for books and staff can always be ignored until next year. 'Next year' never comes."

The cooperation and support of the faculty and administration cannot be taken for granted, but must be sought, maintained, and rewarded by a continuing flow of information on library needs, plans, and prospects. Needless to say the library's educational program should include courses not only for the administration and the faculty, but for students and alumni, the governor and the legislature (or board of trustees), corporations and foundations, and the public, with special tutoring for dropouts.

These remarks are fairly obvious and may strike some as unpleasantly hortatory, but they are not gratuitous. They are intended to stimulate or provoke thought about research libraries and ways and means of increasing their effectiveness even before the National Commission sends its report to the White House. In the appointment of the Commission and in recent legislation, the Administration and the Congress have recognized the importance of libraries, and Federal appropriations to libraries of all kinds have risen to more than six hundred million dollars a year. But no one knows which of the Commission's recommendations will be acted upon, or when any action will begin to touch the research libraries, or whether support for their activities will be increased. But what is done by the individual library with the enthusiastic backing of its own clientele may have important effects beyond the campus. The fact is that the Congress is likely to be more understanding if it learns that research libraries have themselves gone as far as they can with energetic and imaginative measures of self-help.

\section{Are YOU}

a member

of ALA?

Join for 1968 !

Write:

Membership Promotion

American Library Association

50 East Huron Sireet

Chicago, Illinois 60611

\section{CUSHING-MALLOY, INC.}

1350 North Main Street P.O. Box 632

Ann Arbor, Michigan 48107

\section{Printers of Who's Who in Library Service}

\section{LITHOPRINTERS}

Known for

QUALITY - ECONOMY - SERVICE

Let us quote on your next printing 